\title{
Behavior of free omental grafts without vascular anastomosis implanted in cat's experimental wounds
}

\author{
Jorge Gabriel de Cerqueira Teixeira ${ }^{1}$ (D) Mariana Braga Cavalcanti ${ }^{2}(\mathbb{D}$ \\ Maria Eduarda dos Santos Lopes Fernandes ${ }^{1 *}$ (i) Rhudson Victor Vilarinho Silva ${ }^{3}$ (iD \\ Mylena Assis dos $\operatorname{Santos}^{3}$ (iD Diefrey Ribeiro $\operatorname{Campos}^{4}$ (i) Marta Fernanda Albuquerque da Silva ${ }^{5}$ (iD
}

${ }^{1}$ Programa de Pós-graduação em Medicina Veterinária, Instituto de Veterinária, Universidade Federal Rural do Rio de Janeiro (UFRRJ), 23890-000, Seropédica, RJ, Brasil. E-mail: dudalopesfer@hotmail.com. "Corresponding author.

${ }^{2}$ Médica Veterinária Autônoma, Seropédica, RJ, Brasil.

${ }^{3}$ Bolsista de Apoio Técnico do Hospital Veterinário, Universidade Federal Rural do Rio de Janeiro (UFRRJ), Seropédica, RJ, Brasil

${ }^{4}$ Programa de Pós-graduação em Ciências Veterinárias, Instituto de Veterinária, Universidade Federal Rural do Rio de Janeiro (UFRRJ), Seropédica, RJ, Brasil.

${ }^{5}$ Departamento de Medicina e Cirurgia Veterinária, Instituto de Veterinária, Universidade Federal Rural do Rio de Janeiro (UFRRJ), Seropédica, RJ, Brasil.

ABSTRACT: It is known that skin healing in cats is slower and has a higher complication rate than in dogs, what leads to search for new resources to enhance this process. Omentum properties in the aid of tissue repair are known and, among the forms of extraperitoneal omentalization, the use of free omental grafts without vascular anastomosis is advantageous, but little studied; there is no knowledge about its effect on skin healing, nor if it's still viable when implanted in the subcutaneous space. Thus, the present study aimed to describe possible alterations produced by free omental graft without anastomosis inserted in the subcutaneous space, by means of macroscopic clinical analysis of the implantation region in cats. Twenty intact female cats were divided into two groups (Group 1: treated animals; Group 2: controls) of similar size. All animals were subjected to ovariosalpingohysterectomy (OSH) prior to the induction of an experimental wound for the implantation of the omental graft. Wounds were evaluated on days 1, 2, 4, 8, and 15 postsurgery and then weekly until no lesions were noted. Data regarding color, consistency, presence or absence of crusts, wound resistance, and volume measurements were recorded. There was activation of the omentum on the 4th day of evaluation with reduction of hemorrhage and an increase in the resistance to traction of the experimental wound. We concluded that the omentum without vascular anastomosis is capable of maintaining its viability and exert positive influence on the repair process without showing deleterious signs on the implantation site.

Key words: extraperitoneal omentalization, reconstructive surgery, biomaterial.

Comportamento do enxerto omental livre sem anastomose vascular implantado em feridas experimentais de gatos

RESUMO: Sabe-se que a cicatrização de pele em gatos é mais lenta e apresenta índice maior de complicações que nos cães, dai a importância da busca de novos recursos para estimular o processo cicatricial. São conhecidas as propriedades do omento no auxilio ao reparo tecidual e, dentre as formas de omentalização extraperitoneal, o uso do omento livre sem anastomose vascular é vantajoso, porém pouco estudado; não há conhecimento sobre seu efeito na cicatrização cutânea, tampouco se permanece viável quando implantado no espaço subcutâneo. Sendo assim, o presente trabalho tem como objetivo avaliar possiveis alterações produzidas pelo enxerto omental livre sem anastomose inserido no espaço subcutâneo, por meio da avaliação clínica macroscópica da região de implantação em gatos. Foram utilizadas 20 gatas, de idade entre um e sete anos, sem alterações em exame de sangue, FIV/FELV negativas. Os animais foram divididos em dois grupos (Tratado e Controle) de igual tamanho, diferindo quanto à utilização do enxerto de omento livre. Foi realizada cirurgia de ovariossalpingohisterectomia (OSH) em todos os animais, previamente à criação da ferida experimental para implantação ou não do enxerto omental. As feridas foram avaliadas nos dias 1, 2, 4, 8 e 15 do pós-operatório e a partir de então semanalmente, até nenhuma alteração ser observada. Foram anotados dados referentes à coloração, consistência, presença de crosta, resistência da ferida e medidas do volume. Nos resultados destacou-se a ativação do omento no quarto dia de avaliação, observada pelo aumento de volume, com redução de hemorragia e aumento na resistência da ferida experimental à tração. Conclui-se que o omento em sua forma livre sem anastomose é capaz de manter sua viabilidade e exercer influência positiva sobre o processo de reparo, sem demonstrar sinais deletérios sobre a região implantada.

Palavras-chave: omentalização extraperitoneal, cirurgia reconstrutiva, biomaterial.

\section{INTRODUCTION}

Wound is defined as the interruption of the anatomical and functional integrity of the tissues. Wound healing is an orderly and complex process that has been conceptually divided into three overlapping and continuous phases ("the wound healing continuum"): inflammation, repair, and maturation (GUO \& DIPIETRO, 2010). It has been shown that alterations during the healing process are more 
frequently observed in cats than in dogs especially if there is loss of subcutaneous tissue in these patients which may restrict the formation of granulation tissue (BOHLING \& HENDERSON, 2006).

According to the literature, clinical and experimental studies have demonstrated the ability of the omentum to stimulate neovascularization, allow new lymphatic drainage, and potentiate the cicatricial process even in the presence of infection (SCHWARZKOPF et al., 2014). The omentum is used as an aid in the wound healing process mainly due to its vascular richness, and the presence/ synthesis of polypeptides and growth factors that have potent angiogenic properties (ZHANG et al., 1997). Due to the structure of this organ, there is great tissue availability and favorable vascularization (LIEBERMANN, 2000).

The types of omentum grafts that have been described in the literature include pediculate (LASCELLES et al., 1998), free with vascular anastomosis (ROA et al., 1999), and free without vascular anastomosis (REE et al., 2018).

Free omental grafts consist of the complete surgical removal of an omental fragment from its original site (donor region) and transfer (transplantation) to another region (recipient region). Once implanted into the recipient, omental grafts acquire new blood supply ensuring viability of the transplanted cells (PAVLETIC, 2010).

In small animals, the main advantages of the use of a free omental fragment without vascular anastomosis included minimizing the complications associated with pedicled omentum grafts (PETIT et al., 1979; BROCKMAN et al, 1996; LASCELLES et al., 1998) and facilitating the manipulation and implantation of the graft at sites distant from its origin, without requiring specific and expensive surgical materials as observed in the implantation technique of a free omental graft with vascular anastomosis (REE et al., 2018).

With regard to the complications that may be observed when the pedicled omental graft is used, albeit rare, partial necrosis of the omentum is the most frequently reported. This may occur due to a number of reasons including excessive tension on the vascular pedicle, pressure or strangulation at the site of exteriorization in the abdominal cavity or the use of an elongated and narrow subcutaneous tunnel. The presence of defects in the abdominal wall which results in hernia formation can also be observed as a complication during the use of this technique (BROCKMAN, 1996). With regard to the free omentum graft with vascular anastomosis, studies showed that there is still no effective success rate of the technique in veterinary medicine (PAPSZEKERES et al., 2003).

More recently, studies using free omental grafts without vascular anastomosis have demonstrated promising results in aiding fracture repair, reducing mean bone healing time (BALTZER et al., 2015) and stimulating osteogenesis in hypertrophic nonunion (SAIFZADEH et al., 2009). BALTZER et al. (2015) used free omental grafts in the osteosynthesis of radial and ulnar fractures of dogs. These authors reported that the main complications reported in the surgical site were the difficulty in suturing the skin due to the presence of graft, edema, swelling, and erythema. These complications resolved 3 to 5 days following the surgery. Complete resolution of these complications occurred at day 7 postsurgery.

To the authors' knowledge, there are no published studies to date on the use of free omental graft as an aid in skin wound healing, and its behavior when implanted in the subcutaneous space has not been described. For this reason, the aim of this study was to evaluate possible alterations produced by free omental graft without anastomosis in the implantation region through macroscopic clinical analysis.

\section{MATERIALS AND METHODS}

Twenty female cats aged between 1 and 7 years old, originated from the Experimental Chemistry unit of the Veterinary Parasitology Laboratory (LQEPV) of the Federal Rural University of Rio de Janeiro (UFRRJ) that were subjected to elective ovariosalpingohysterectomy $(\mathrm{OSH})$ were used in this study.

The animals were subjected to a full physical examination and laboratory evaluation that consisted of complete blood chemistry and $\mathrm{CBC}$ analysis including renal and hepatic function assessment and FIV/FeLV testing. Cats that presented any abnormalities in these laboratory tests were removed from the study.

All patients were subjected to the evaluation of the body condition scoring (BCS) on a previously published scale of 1 to 5 points according to EDNEY \& SMITH (1986).

The animals were allocated into 2 groups of 10 cats each which differed in the use of free omentum. In the Treated Group (TG), a free omental graft without vascular anastomosis was placed under the experimental surgical wound of the skin whereas in the Control Group (CG) the procedure of synthesis of the experimental wound was performed without using the omentum.

Surgeries were performed at the Surgical Research and Extension Center (CCPE) of the 
Veterinary Institute of UFRRJ. Animals were put under general inhalation anesthesia, placed in dorsal recumbency, and median retroumbilical celiotomy and OSH surgery were performed. At the end of the OSH and prior to the celiorrhaphy, a fragment of the greater omentum was removed from the animals of the TG. The omentum was folded in order to expose its ventral aspect and, on the right side of the bursal portion, two blood vessels of the right gastroepiploic arcade were identified to limit the width of the fragment. The extension was obtained $2.5 \mathrm{~cm}$ to 3 $\mathrm{cm}$ from the caudal border of the omental pouch. After vascular ligation with 3-0 polyglactin 910, the omental fragment was excised and stored in sterile lactated Ringer's solution.

The abdominal wall musculature was sutured in standard $\mathrm{X}$ with 3-0 polyamide and subcutaneous cellular tissue with continuous suture using 3-0 absorbable polyglactin 910 .
Prior to skin suturing, another incision of approximately $2 \mathrm{~cm}$ long located $1 \mathrm{~cm}$ cranial to the incision for OSH was made and was considered as the experimental wound. Such incision involved skin and subcutaneous tissue. For the production of a receptor bed, the subcutaneous tissue was drawn on each side of the incision in order to remove a fragment approximately $0.5 \mathrm{~cm}$ wide over the entire length of the incised skin. These procedures were performed in cats of both groups (TREATED and CONTROL).

The omental fragment maintained in sterile lactated Ringer's solution was then manipulated into a metal vat, and a portion of the omentum measuring approximately $2.0 \mathrm{~cm} \times 1.0 \mathrm{~cm}$ was surgically removed. This tissue fragment was fixed to the muscular fascia with single stitches using 3-0 polyamide suture at each vertex of the experimental surgical wound on animals of the TG (Figure 1). Separate single points were used for skin raffia with 3 sutures made in

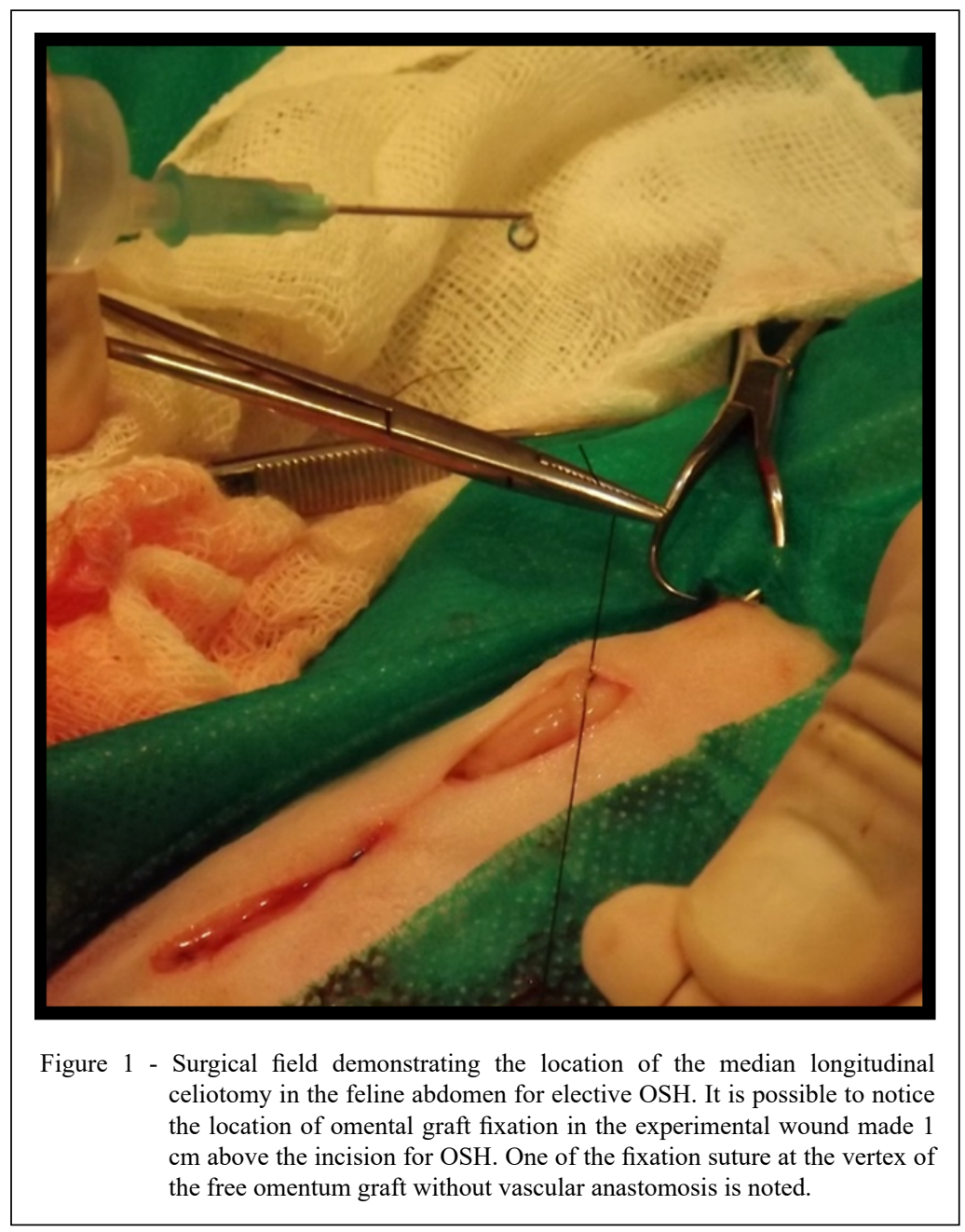

Ciência Rural, v.50, n.9, 2020. 
the experimental wound and 4 sutures in the other surgical wound totaling 7 single sutures.

Postoperative treatment consisted of broad-spectrum antibiotic therapy with benzathine penicillin in single dose $(40.000 \mathrm{U} / \mathrm{Kg}$; Intramuscular route) right after the surgery, anti-inflammatory therapy with meloxicam $(0.1 \mathrm{mg} / \mathrm{kg}$; Oral route; SID; 4 days), and analgesia with dipyrone $(25 \mathrm{mg} / \mathrm{kg}$; Oral route; BID; 5 days) and tramadol hydrochloride (1mg/kg; Oral route; BID; 5 days). The animals wore a protective plastic collar until the stitches were removed.

Before cats were restrained for wound evaluation, the behavior of these animals while they were still inside individual cages was analyzed and videotaped. The animals' interest in the environment and in their surroundings were considered during this assessment. The cage's door was opened and the animal's reaction was observed. The physical interaction between the animal and the researcher consisted of gentle, smooth, slow movements until he or she was allowed to touch the animal's flank and the wounds for local pain assessment. In doing so, interest in moist food and appetite were also assessed.

Experimentally induced wounds were evaluated on days $1,2,4,8$ and 15 when the stitches were removed. After this period of time (time span), the evaluations were performed weekly in animals from the TG only until the volume of the omentum implantation region could no longer be noticed or measured.

Data on the gross aspect of the wounds (TATARUNAS et al., 1998) were recorded on written form and scored as: color ( 0 - no changes were noted in the surgical wound; the wound was compared with the integrated skin in the animal's abdomen, 1 pinkish wound, 2 - reddish/purple wound); presence or absence of crusts on the surgical wound $(0$ absence of crusts, 1 - mild crusting of the surgical wound, 2 - moderate crusting of the surgical wound, 3 - severe crusting of the surgical wound); wound strength (1 - suture dehiscence, 2 - spontaneous separation of the wound edge, 3 - separation of the wound edge under slight tension - when slight traction is made on the surgical wound, 4 - healing without the possibility of separation of the wound edge); palpation of the omentum implantation site (1 - the omentum implantation site was soft to the touch; the consistency of the omental graft site was similar to the consistency of the omentum; 2 - the omentum implantation site was firm to the touch - the consistency of the omental graft site was similar to the consistency of the abdominal wall).
A pachymeter was used to measure length, width and height of the omentum implantation site. These measurements were then recorded in written form.

The difference between the moments of the measurements of length, width, and height of the experimentally induced wound site was analyzed using the Kruskal-Wallis test and measured with the Dunn's multiple comparison test considering a significant difference when $\mathrm{P}<0.05$.

\section{RESULTS AND DISCUSSION}

The most striking and significant change observed in the omental graft implantation site was the marked increase in volume (Figure 2) which was noted $72 \mathrm{~h}$ postsurgery as shown in table 1 . Prior to this, no increase in volume was felt on palpation of the experimental wound. It is suggested that this is the time span required for the graft to form adhesions and vascular branches (THOMPSON, 1945) and releases its growth factors at the implantation site. This change in volume, which is referred to as "activated omentum", is possibly related to the release of endothelial growth factor (VEGF), since the omentum is considered a primary and excellent source of VEGF compared to other tissues of the body (ZHANG et al., 1997; LITBARG et al., 2007).

Until the $15^{\text {th }}$ day this volume could be noticed by palpation and measured with the aid of a pachymeter in all animals from the TG. The volume of the experimentally induced wound site could still be detected by palpation even several days after surgery. However, it was no longer possible to clearly delineate the extent and depth of the surgical wound and to measure it in the animals evaluated. The period of time in which the volume of the omental implant site could still be noticed on visual inspection and palpation and measured varied between 15 and 35 days, with an average of 25 days. After this period of time, weekly visits were done in order to assess these wounds until it was no longer possible to feel any volume in the omental grafting at the implant site. Few studies have described the behavior of a free omental at the graft fixation site. BALTZER et al. (2015) noted a local increase in volume with resolution of all cases on day 7 postsurgery. Our results are not in agreement with those previously published by these researchers as in the present study a reduction in volume of the omental graft was noticed on day 15 postsurgery. One hypothesis that may explain the slow graft regression would be differences in the vascularization of the implantation site. In the study 


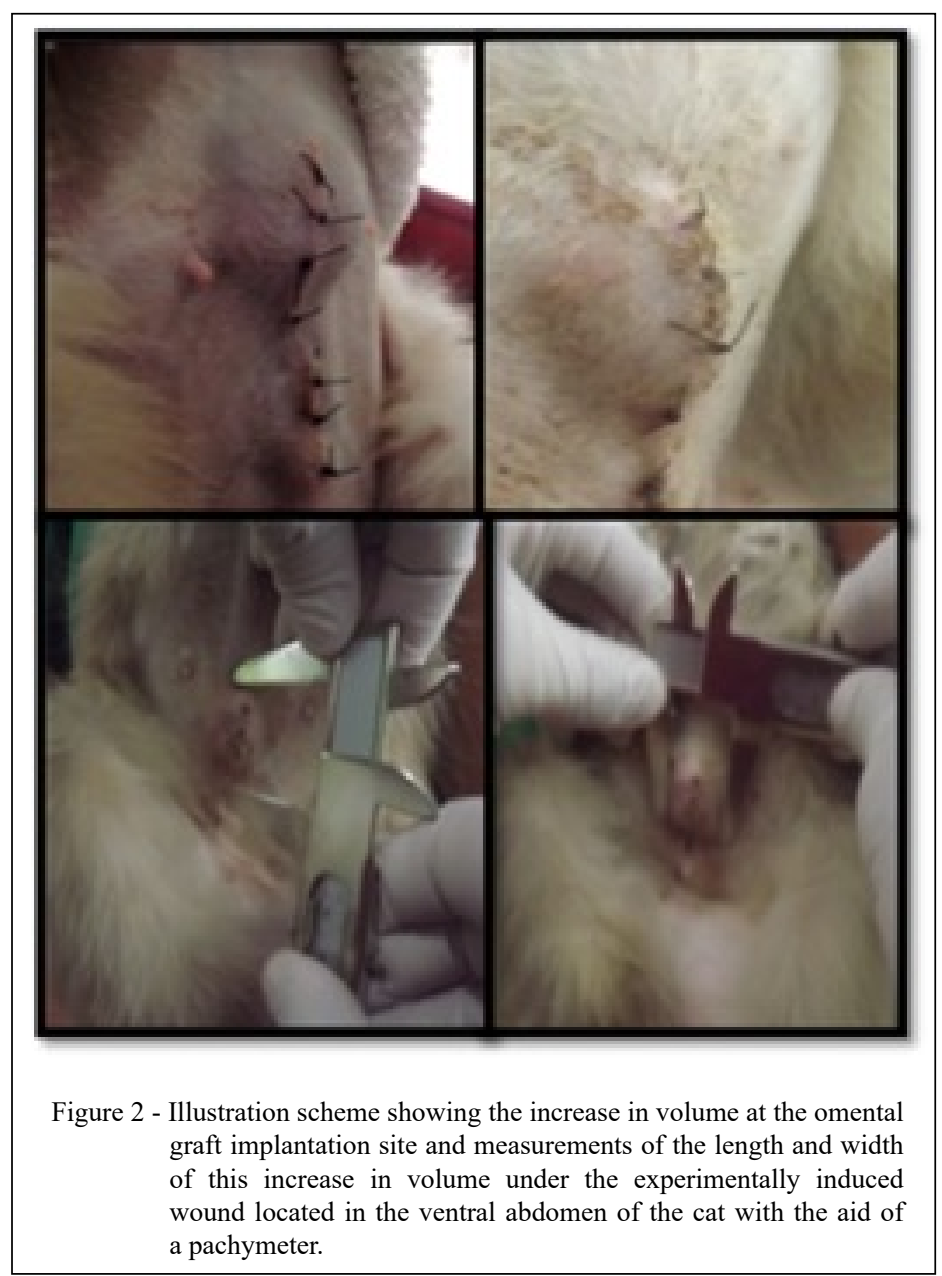

carried out by BALTZER et al. (2015), free omentum was implanted on bone fractures surrounded by muscular tissue which is richer in vascularization than the subcutaneous tissue which is the site of implantation in the present study. Therefore, we may infer that the inflammation processes and repair have occurred more slowly.

In 2 animals from the $\mathrm{TG}$, bilateral increase in volume of the mammary glands was observed. Such increase size was noted in the thoracic mammary glands and in the abdominal mammary glands as well. We may attribute such enlargement of the mammary glands to the angiogenic effect of the omental tissue in view of the marked increase from the intimate contact between the omental fragment and the abdominal mammary glands. The paracrine capacity and signaling of the omental adipose tissue (ZHANG et al., 1997) has been reported in the literature in conjunction with the aforementioned richness in the production of VEGF and mammary gland stimulation may be attributed to omentum activation and release of these factors. For this reason, care should be taken in the selection of animals subjected to omental grafting. Omental grafting should be discouraged in those animals with a diagnosis or suspicion of neoplasia.

The resistance of the experimental wound presented a significant advantage in the $\mathrm{TG}$ in the 2 days of evaluation of this parameter, as shown in figure 3. Such advantage was attributed to the presence of the omental graft in the subcutaneous space fixed in the muscular fascia due to its scarring potential (ZHANG et al, 1997). Although, in the CG the wound had presented a small dead space due to the removal of the subcutaneous tissues, that is primordial for feline wound healing, it is considered that there was 
Table 1 - Median values of measurements obtained on the body surface at a site corresponding to the implantation of a free omentum fragment without vascular anastomosis in the subcutaneous space underlying the experimental wound in 10 cats.

\begin{tabular}{|c|c|c|c|}
\hline Days & LENGHT Median & WIDTH Median & HEIGHT Median \\
\hline 0 & 2.0 & $0.0^{\mathrm{af}}$ & $0.0^{\mathrm{ab}}$ \\
\hline 1 & $1.6^{\mathrm{a}}$ & $1.2^{\mathrm{bc}}$ & $0.1^{\mathrm{cd}}$ \\
\hline 2 & $1.45^{\mathrm{bc}}$ & $1.0^{\mathrm{de}}$ & $0.1^{\text {ef }}$ \\
\hline 4 & $2.7^{\mathrm{abd}}$ & $2.3^{\mathrm{abd}}$ & $0.5^{\text {ace }}$ \\
\hline 8 & $2.35^{\mathrm{c}}$ & $2.1^{\mathrm{cef}}$ & $0.5^{\text {bdf }}$ \\
\hline 15 & $1.7^{\mathrm{d}}$ & 1.25 & 0.3 \\
\hline
\end{tabular}

${ }^{\text {abcd }}$ Similar letters in the same column show statistically significant difference.

no negative influence on the cicatricial process since an extensive tissue loss is necessary for impairment of wound healing (BOHLING et al., 2006).

In the first $48 \mathrm{~h}$, both groups of animals showed differences in the color of the surgical wounds. The TG had a low staining score compared to the CG which had a higher staining score in the first couple of days (Figure 4). This fact may be related to the action of the graft as a natural hemostatic agent (THOMPSON, 1945; HOSGOOD, 2006; KOPPE et al., 2014) and also by the modulation of the local inflammatory reaction due to its presence in the dead space left by the withdrawal of the subcutaneous tissue. From day 4 onwards it was possible to notice an increase in the staining score in the TG which persisted for a longer period of time when compared to the CG. This may have occurred due to the fact that this is the time when the omental graft is activated generating a more pronounced metabolic process.

Most of the cats had a body condition scoring (BCS) 3 corresponding to the normal condition. Two animals of the TG were classified as

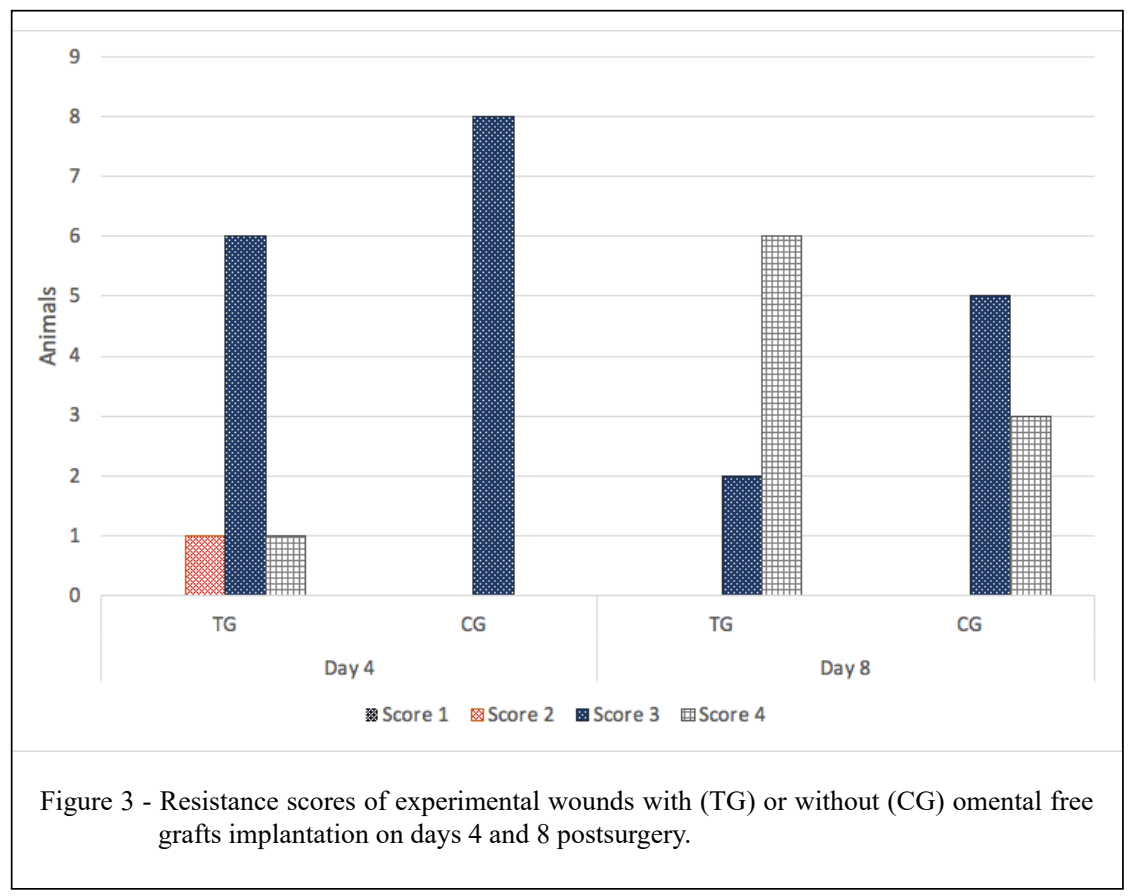

Ciência Rural, v.50, n.9, 2020. 


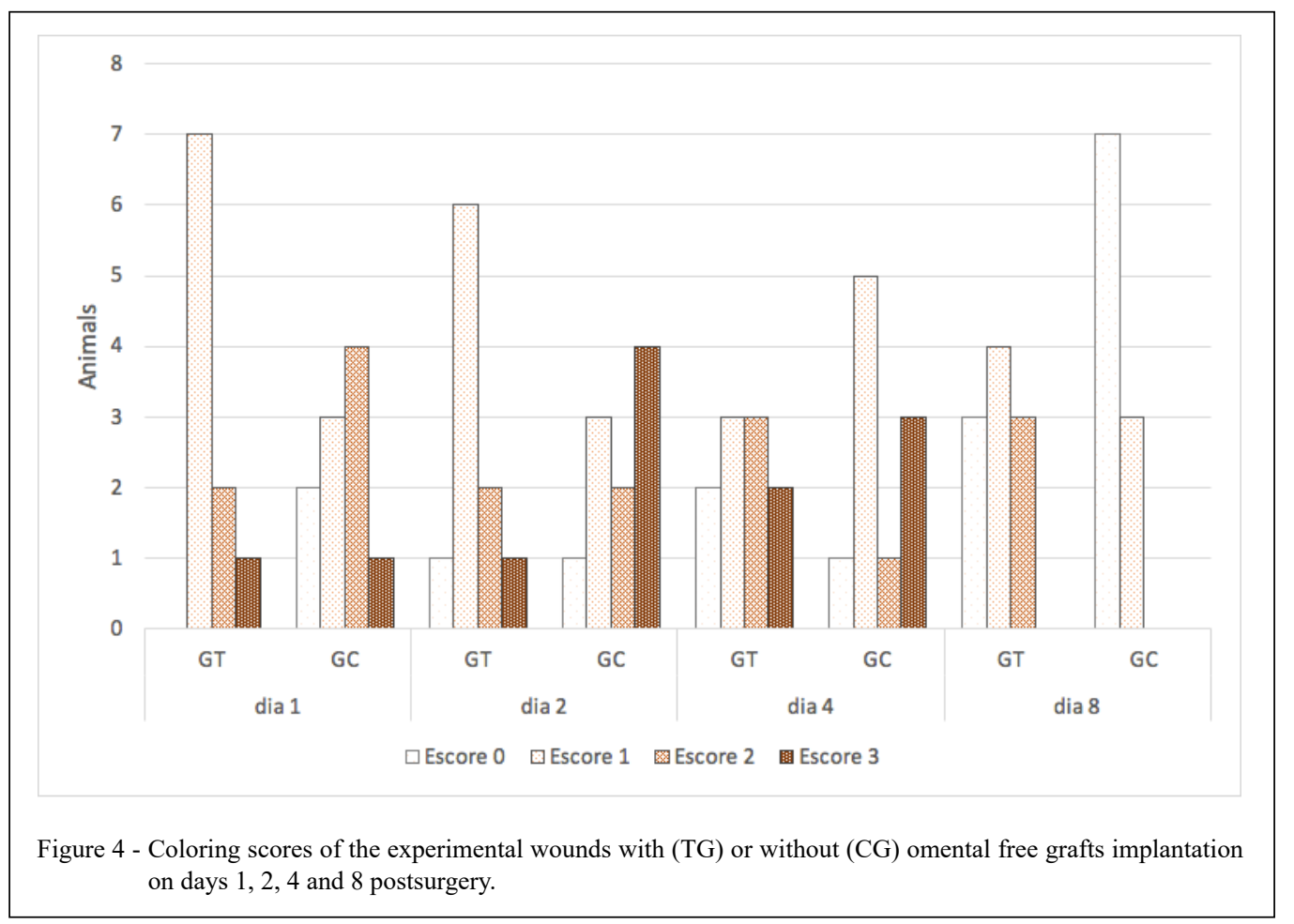

obese (BCS 5) and in the CG 1 animal had a body condition score 2. The two animals classified with BCS 5 presented a more severe inflammatory process and wound color changes persisted after the 10th day postsurgery. The omental implant in an obese animal should be evaluated with greater care as the omentum is equally greasy. These animals showed marked exudate/discharge during the wound healing process, increased crust formation, and changes in wound color for a longer period of time when compared to the other animals of the same group. This may be related to the prolongation of the inflammatory process (PAZ-FILHO, 2012).

With regard to the consistency of the lesion, in the first 4 days the omentum graft was soft and slightly mobile. At the end of 1 week, it was mostly firm and non-mobile. Our findings do not corroborate those from Thompson's report published in 1945 in which, at the end of $72 \mathrm{~h}$, the free omentum graft applied to the lung lesion was firmer. It was also reported that at the end of 1 week there was absorption of the adipose tissue, and the graft could be separated with difficulty. In an experimental study in which the rat tibia was used, the free omental graft showed changes in consistency and became a firm tissue attached to the bone within 14 days postsurgery
(OLOUMI et al., 2006). This change in consistency may be related to the absorption of the adipose tissue and fixation at the implanted site emphasizing its adherence ability.

There was no difficulty in skin suturing of the experimental wound with the presence of the omentum graft as previously reported by BALTZER et al. (2015). This is probably due to the fact that part of the subcutaneous tissue at the implant site was removed. In addition, BALTZER et al. (2015) implanted the graft on fractures with a metal implant in bones with little muscle covering.

The literature on use of a free omental graft without vascular anastomosis is scarce as there are few published studies on the subject to date. To the authors' knowledge, there are no articles on the patency of the free omental grafts in soft tissue and skin wounds which are of paramount importance in clinical studies.

\section{CONCLUSION}

Based on our findings, we concluded that the free omentum without vascular anastomosis is able to maintain its viability when applied in the subcutaneous tissue of cats without deleterious effects of the graft over the implanted region. 


\section{ACKNOWLEDGEMENTS}

This study was financed in part by the Coordenação de Aperfeiçoamento de Pessoal de Nível Superior (CAPES), Brasil - Finance code 001."

\section{BIOETHICS AND BIOSSECURITY COMMITTEE APPROVAL}

The research project was approved by the Ethics Committee on the Use of Animals in Research (CEUA) of the Veterinary Institute of the Universidade Federal Rural do Rio de Janeiro (UFRRJ), Seropédica, RJ, Brazil, accession number 7358110617.

\section{DECLARATION OF CONFLICT OF INTERESTS}

The authors declare no conflict of interest. The founding sponsors had no role in the design of the study; in the collection, analyses, or interpretation of data; in the writing of the manuscript, and in the decision to publish the results.

\section{AUTHORS' CONTRIBUTIONS}

The authors contributed equally to the manuscript.

\section{REFERENCES}

BALTZER, W. I. et al. Augmentation of diaphyseal fracture of the radius and ulna in toy breed dogs using a free autogenous omental graft and bone plating. Veterinary and Comparative Orthopaedics and Traumatology, v.28, p.131-139, 2015. Available from: <https://www.thieme-connect.com/products/ ejournals/abstract/10.3415/VCOT-14-02-0020>. Accessed: May, 19, 2020. doi: 10.3415/VCOT-14-02-0020.

BOHLING, M. W., HENDERSON, R. A. Differences in cutaneous Wound Healing Between Dogs and Cats. Veterinary Clinics Small Animal Practice; v.36, p687-692, 2006. Available from: $\quad<$ https://www.sciencedirect.com/science/article/abs/pii/ S0195561606000180?via\%3Dihub> Accessed: May, 19, 2020. doi: 10.1016/j.cvsm.2006.02.001.

BOHLING, M.W. et al. Comparison of the role of the subcutaneous tissues in cutaneous wound healing in the dog and cat. Veterinary Surgery, v.35, p.3-14, 2006. Available from: $<$ https://onlinelibrary. wiley.com/doi/abs/10.1111/j.1532-950X.2005.00105.x> Accessed: May, 19, 2020. doi: 10.1111/j.1532-950X.2005.00105.x.

BROCKMAN, D.J. et al. Omentum-enhanced reconstruction of chronic nonhealing wounds in cats: techniques and clinical use. Veterinary Surgery, v.25, n.2, p.99-104, 1996. Available from: $\quad<$ https://onlinelibrary.wiley.com/doi/abs/10.1111/j.1532950X.1996.tb01384.x?sid=nlm\%3Apubmed $>$. Accessed: May, 19, 2020. doi: 10.1111/j.1532-950x.1996.tb01384.x.

EDNEY, A.T.B.; SMITH, P.M. Study of obesity in dogs visiting veterinary practices in the United Kingdom. Veterinary Record, v.118, p.391-396, 1986. Available from: <https://veterinaryrecord. bmj.com/content/118/14/391>. Accessed: May, 19, 2020. doi: 10.1136/vr.118.14.391.
GUO S., DIPIETRO L. A. Factors affecting wound healing. Journal of Dental Research. V.89, p.219-229, 2010. Available from: $<$ https://www.ncbi.nlm.nih.gov/pmc/articles/PMC2903966/>. Accessed: May, 19, 2020. doi:10.1177/0022034509359125.

HOSGOOD, G. Stages of wound healing and their clinical relevance. Veterinary Clinics Small Animal Practice; v.36, p.667-685, 2006. Available from: <https://www.sciencedirect. com/science/article/abs/pii/S0195561606000234?via\%3Dihub>. Accessed: May, 19, 2020. doi: 10.1016/j.cvsm.2006.02.006.

KOPPE, M. J. et al. Recent insights into the pathophysiology of omental metastases. Journal of Surgical Oncology. v10, p.670675, 2014. Available from: <https://onlinelibrary.wiley.com/doi/ abs/10.1002/jso.23681>. Accessed: May, 19, 2020. Epub 24-Jun2014. doi: 10.1002/jso.23681.

LASCELLES, B.D.X. et al. Use of omental pedicle grafts in the management of nonhealing axillary wounds in 10 cats. Journal of Small Animal Practice, v.39, p.475-480, 1998. Available from: <https://onlinelibrary.wiley.com/doi/ abs/10.1111/j.1748-5827.1998.tb03682.x? sid=nlm\%3Apubmed $>$. Accessed: May, 19, 2020. doi: 10.1111/j.1748-5827.1998. tb03682.x.

LIEBERMANN-MEFFERT, D. The greater omentum. Surgical Clinics of North America, v.80, n.1, p.27-293, 2000. Available from: $\quad<$ https://www.surgical.theclinics.com/article/S00396109(05)70406-0/abstract>. Accessed: May, 19, 2020. doi: 10.1016/S0039-6109(05)70406-0.

LITBARG, N.O. et al. Activated omentum becomes rich in factors that promote healing and tissue regeneration. Journal of Cell \& Tissue Research. v.328, p.487-497, 2007. Available from: $<$ https://link.springer.com/article/10.1007/s00441-006-03564>. Accessed: May, 19, 2020. Epub 14-Feb-2007. doi: 10.1007/ s00441-006-0356-4.

OLOUMI, M.M.; DERAKHSHANFAR, M.M.; TAYYEBI, M. The angiogenic potential of autogenous free omental graft in experimental tibial defects in rabbits: short-term preliminary histopathological study. Journal of Experimental Animal Sciencei. v43, p.179-187, 2006. Available from: <https://www. sciencedirect.com/science/article/abs/pii/S0939860006000046>. Accessed: Mai 19, 2020. doi: 10.1016/j.jeas.2006.02.002.

PAP-SZEKERES, J. et al. Transplantation and microsurgical anastomosis of free omental grafts: Experimental animal model of a new operative technique in dogs. Microsurgery, v23, n.5, p414-418, 2003. Available from: $<$ https://onlinelibrary.wiley.com/doi/abs/10.1002/ micr.10176>. Accessed: May, 19, 2020. doi: 10.1002/micr.10176.

PAVLETIC, M.M.; Free grafts. Atlas of Small Animal Wound Management and Reconstructive Surgery. $3^{\text {rd }}$ ed., Iowa: Blackwell, 2010. cap.14, p.403.

PAZ-FILHO, G. et al. Leptin: molecular mechanisms, systemic pro-inflammatory effects, and clinical implications. Arquivos Brasileiros de Endocrinologia e Metabologia. v56, n.9, p.597607, 2012. Available from: <https://www.scielo.br/scielo. php?script=sci_abstract\&pid=S0004-27302012000900001\&lng= pt\&nrm=iso\&tlng=en>. Accessed: May, 19, 2020. doi: 10.1590/ S0004-27302012000900001.

PETIT, J.Y. et al. Indications and results of omental pedicle grafts in oncology. Cancer. v.44, n.6, p.2343-2348, 1979. 
Available from: < https://acsjournals.onlinelibrary.wiley.com/doi/ abs/10.1002/1097-0142\%28197912\%2944\%3A6\%3C2343\%3A \%3AAID-CNCR2820440651\%3E3.0.CO\%3B2-T>. Accessed: May, 19, 2020. doi: 10.1002/1097-0142(197912)44:6<2343::aidcncr2820440651>3.0.co;2-t.

REE, J.J.; BALTZER, W.I.; NEMANIC, S. Randomized, controlled, prospective, clinical trial of autologous greater omentum free graft versus autogenous cancellous bone graft in radial and ulnar fractures in miniature breed dogs. Veterinary Surgery. v.1, n.14, p.1-14, 2018. Available from: $<$ https://onlinelibrary.wiley.com/doi/ abs/10.1111/vsu.12774>. Accessed: May, 19, 2020. Epub 19-Feb2018. doi: $10.1111 /$ vsu. 12774 .

ROA, D.M.; BRIGHT, R.M.; DANIEL, G.B. Microvascular transplantation of a free omental graft to the distal extremity in dogs. Veterinary Surgery, v.28, p.456-465, 1999. Available from: $<$ https://onlinelibrary.wiley.com/doi/abs/10.1111/j.1532-950X.199 9.00456.x? sid=nlm\%3Apubmed $>$. Accessed: May, 19, 2020. doi: 10.1111/j.1532-950x.1999.00456.x.

SAIFZADEH, S. et al. Autogenous greater omentum, as a free nonvascularized graft, enhances bone healing: an experimental nonunion model. Journal of Investigative Surgery. v22, n.2, p129-37, 2009. Available from: <https://www.tandfonline.com/ doi/full/10.1080/08941930802566730>. Accessed: May, 19, 2020. doi: $10.1080 / 08941930802566730$.
SCHWARZKOPF, I. et al. Surgical repair of a congenital sternal cleft in a cat. Veterinary Surgery, v.43, n.5, p.623-9, 2014. Available from: <https://onlinelibrary.wiley.com/doi/full/10.1111/ j.1532-950X.2014.12226.x>. Accessed: May, 19, 2020. Epub 7-Jun-2014. doi: 10.1111/j.1532-950X.2014.12226.x.

TATARUNAS A. C, MATERA J. M., DAGLi M. L. Z. Estudo clínico e anátomopatológico da cicatrização cutânea no gato doméstico: utilização do laser de baixa potência AsGa (904 nm). Acta Cirúrgica Brasileira v.13, p.86-93, 1998. Available from: $\quad<$ https://www.scielo.br/scielo.php?script=sci arttext\&pid $=$ S0102-86501998000200004 $>$. Accessed: May, 19, 2020. doi: $10.1590 / \mathrm{S} 0102-86501998000200004$.

THOMPSON, S. A.; POLLOCK, BORIS. The use of free omental grafts in the thorax. American Journal of Surgery. v.70, n.2, P.227-231, 1945. Available from: <https://www. americanjournalofsurgery.com/article/0002-9610(45)90215-7/ fulltext $>$. Accessed: May, 19, 2020. doi: 10.1016/00029610(45)90215-7.

ZHANG, Q.X. et al. Vascular endothelial growth factor is the major angiogenic factor in omentum: Mechanism of the omentum-mediated angiogenesis. Journal of Surgical Research. v.67, n.2, p.147-154, 1997. Available from: <https://www. journalofsurgicalresearch.com/article/S0022-4804(96)94983-5/ pdf>. Accessed: May, 19, 2020. doi: 10.1006/jsre.1996.4983. 